\title{
Unusual Transformations in Diphosphine-Bridged Diruthenium(I) Complexes; Reactions with a Ru-Ru Triple Bond Bearing Four Bridging Ligands
}

\author{
Kom-Bei Shiu,* Shiow-Shiang Young, Shung-I Chen, J iun-Yu Chen, and \\ Hsiang-J en Wang
}

Department of Chemistry, National Cheng Kung University, Tainan, Taiwan 701

Sue-Lein Wang and Fen-Ling Liao

Department of Chemistry, National Tsing Hua University, Hsinchu, Taiwan 300

Shie-Ming Peng and Yi-Hung Liu

Department of Chemistry, National Taiwan University, Taipei, Taiwan 106

Received J uly 6, 1999

Summary: A series of Ru-Ru triply bonded dimers, $\left[\mathrm{Ru}_{2}(\mu-\mathrm{CO})_{2}(\mu \text {-DPPM })_{2} \mathrm{X}_{2}\right]$, is obtained quite readily in an unusual way. Despite the presence of the four bridging ligands, the rich chemistry concerning the multiple bond is still accessible via relocation of one or two carbonyl groups.

Binuclear complexes of two bridging bis(diphenylphosphino)methane (DPPM) ligands have continually attracted a great deal of attention for many years because of their rich chemistry and potential as catalysts, catalyst precursors, or model compounds to study the metal-metal cooperativity effects in binding and activation of substrates. ${ }^{1}$ Our recent discovery of conditioned $\mathrm{P}-\mathrm{CH}_{2}$ bond cleavage for one "unstable" DPPM in a scarcely studied cationic diruthenium(I) system ${ }^{2}$ has prompted us to investigate this type of compound systematically. However, we now wish to report here some unusual transformations (Scheme 1$)^{3}$ that occurred for the system with two "stable" DPPM ligands.

We described previously that the bridging acetate ligands in $\left[\mathrm{Ru}_{2}(\mathrm{CO})_{4}(\mu-\mathrm{OAC})_{2} \mathrm{~L}_{2}\right]$ can be removed by using alkylating agents such as $\mathrm{Et}_{3} \mathrm{O}^{+} \mathrm{BF}_{4}{ }^{-}$in $\mathrm{MeCN}$ to form the versatile cations $\left[\mathrm{Ru}_{2}(\mathrm{CO})_{4}(\mathrm{MeCN})_{4} \mathrm{~L}_{2}\right]^{2+}{ }^{4}$ However, when a similar treatment was applied to $\left[\mathrm{Ru}_{2}-\right.$ $\left.(\mathrm{CO})_{4}(\mu \text {-DPPM })_{2}(\mu-\mathrm{OAC})\right]^{+}[\mathbf{1}]^{+}$, both NMR and IR spectra indicated that the presumed cation $\left[\mathrm{Ru}_{2}(\mathrm{CO})_{4}(\mu\right.$ DPPM $\left.)_{2}(\mathrm{MeCN})_{2}\right]^{2+}$ was indeed formed but then transformed immediately (and gradually even at ambient temperature) into $\left[\mathrm{Ru}_{2}(\mu-\mathrm{CO})_{2}(\mu \text {-DPPM })_{2}(\mathrm{MeCN})_{4}\right]^{2+}$ $\left([2]^{2+}\right)$, isolated as $\mathrm{BF}_{4}^{-}$and $\mathrm{PF}_{6}{ }^{-}$salts. ${ }^{5}$ The structure

* To whom correspondence should be addressed. Fax: (+886) 6274 0552. E-mail: kbshiu@mail.ncku.edu.tw.

(1) (a) Puddephatt, R. J . Chem. Soc. Rev. 1983, 12, 99. (b) Balch, A. L. Homogeneous Catalysis with Metal Phosphine Complexes; Pignolet, L. H., Ed.; Plenum: New York, 1983; pp 167-213. (c) Chaudret, B.; Delavaux, B.; Poilblanc, R. Coord. Chem. Rev. 1988, 86, 191. (d) Shriver, D. F.; Kaesz, H. D.; Adams, R. D. The Chemistry of Metal Cluster Complexes, VCH: New York, 1990.

(2) Shiu, K.-B.; J ean, S.-W.; Wang, H.-J .; Wang, S.-L.; Liao, F.-L.; Wang, J.-C.; Liou, L.-S. Organometallics 1997, 16, 114.

(3) Acceptible analyses were obtained for all new compounds.

(4) Shiu, K.-B.; Li, C.-H.; Chan, T.-J .; Peng, S.-M.; Cheng, M.-C.; Wang, S.-L.; Liao, F.-L.; Chiang, M. Y. Organometallics 1995, 14, 524.

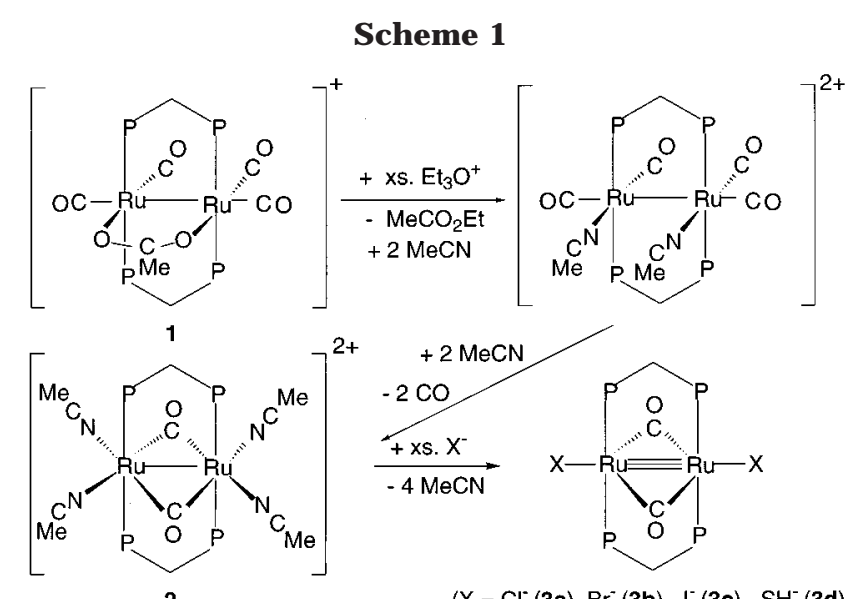

$\left(X=\mathrm{Cl}^{-}(\mathbf{3 a}), \mathrm{Br}^{-}(\mathbf{3 b}), \mathrm{I}^{-}(\mathbf{3 c}), \mathrm{SH}^{-}(\mathbf{3 d})\right.$ Stol (3e), S'Pr $^{-}(\mathbf{3 f}), \mathrm{N}_{3}^{-}(\mathbf{3 g})$ )

3b $\stackrel{+2 \mathrm{PhCH}_{2} \mathrm{NC}}{\longrightarrow}\left[\mathrm{Ru}_{2}\left(\mathrm{Br}_{2}(\mu-\mathrm{CO}) \mathrm{CO}(\mu-\mathrm{DPPM})_{2}\left(\mathrm{PhCH}_{2} \mathrm{NC}_{2}\right](4)\right.\right.$

3a $\quad+\mathrm{Me}_{3} \mathrm{NO}_{2} \mathrm{H}_{2} \mathrm{O}$

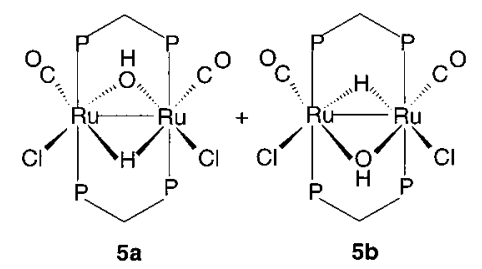

of $[2]^{2+}$ was confirmed by X-ray diffraction methods to adopt a geometry with idealized $D_{2 h}$ symmetry, with four terminal $\mathrm{MeCN}$ and two bridging carbonyl ligands (F igure 1). ${ }^{6}$ This geometry persists in solution, as shown by a virtual ${ }^{1} \mathrm{H}$ NMR quintet for the methylene hydro-

(5) Procedure for 2: In a $100 \mathrm{~mL}$ Schlenk flask was added [1]PF $(1.734 \mathrm{~g}, 1.348 \mathrm{mmol}), 20 \mathrm{~mL}$ of $\mathrm{MeCN}$, and $4 \mathrm{~mL}$ of $1 \mathrm{M} \mathrm{Et}_{3} \mathrm{O}^{+} \mathrm{BF}_{4}{ }^{-}$ solution in $\mathrm{CH}_{2} \mathrm{Cl}_{2}$ at ambient temperature. The mixture was then heated at $82{ }^{\circ} \mathrm{C}$ for $17 \mathrm{~h}$ and cooled to ambient temperature. A 0.609 g portion of $\mathrm{NH}_{4}{ }^{+} \mathrm{PF}_{6}{ }^{-}$(95\% purity, $4.05 \mathrm{~mol}$ ), dissolved in $10 \mathrm{~mL}$ of $\mathrm{MeOH}$, was added to the solution. After the mixture was stirred for $0.5 \mathrm{~h}$, the volume of the solution was reduced to ca. $2 \mathrm{~mL}$ and then added to $10 \mathrm{~mL}$ of $\mathrm{MeOH}$. Filtration gave the pink product [2][PF 6 ] (1.705 g, 85\% yield). 


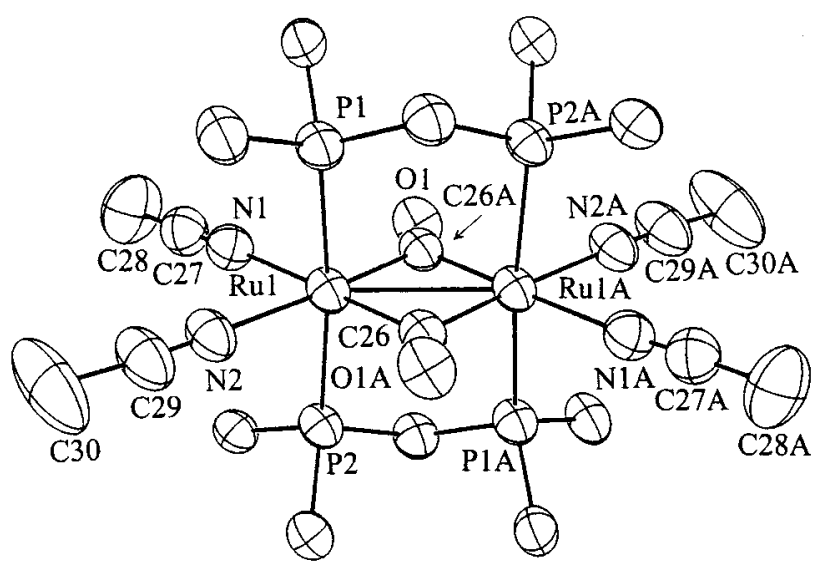

Figure 1. ORTEP diagram of [2] ${ }^{+}$showing $50 \%$ thermal ellipsoids and the numbering scheme (only the ipso carbon atoms of each phenyl group have been retained for clarity). An inversion center is imposed crystallographically at the center of the Ru-Ru bond. Selected bond lengths $(\AA)$ : Ru$(1)-R u(1 A)=2.7703(7), R u(1)-P(1)=2.3875(12), R u(1)-$ $\mathrm{P}(2)=2.3951(12), \mathrm{Ru}(1)-\mathrm{C}(26)=2.002(5), \mathrm{C}(26)-\mathrm{O}(1)=$ $1.192(5), \mathrm{Ru}(1)-\mathrm{N}(1)=2.156(4), \mathrm{N}(1)-\mathrm{C}(27)=1.132(6)$, $\mathrm{C}(27)-\mathrm{C}(28)=1.454(8), \mathrm{Ru}(1)-\mathrm{N}(2)=2.139(4), \mathrm{N}(2)-$ $C(29)=1.115(6), C(29)-C(30)=1.465(8)$. Selected bond angles (deg): $\mathrm{Ru}(1 \mathrm{~A})-\mathrm{Ru}(1)-\mathrm{P}(1)=92.18(3), \mathrm{Ru}(1 \mathrm{~A})-\mathrm{Ru}-$ $(1)-P(2)=93.37(3), C(26)-R u(1)-N(1)=89.78(17), N(1)-$ $\mathrm{Ru}(1)-\mathrm{N}(2)=82.76(16), \mathrm{N}(2)-\mathrm{Ru}(1)-\mathrm{C}(26 \mathrm{~A})=93.79(18)$, $\mathrm{C}(26 \mathrm{~A})-\mathrm{Ru}(1)-\mathrm{C}(26)=93.71(18), \mathrm{Ru}(1)-\mathrm{C}(26)-\mathrm{O}(1)=$ 135.3(4), Ru(1)-C(26)-Ru(1A) = 86.29(18), Ru(1)-N(1)$\mathrm{C}(27)=174.4(4), \mathrm{N}(1)-\mathrm{C}(27)-\mathrm{C}(28)=177.4(6), \mathrm{Ru}(1)-$ $\mathrm{N}(2)-\mathrm{C}(29)=178.6(5), \mathrm{N}(2)-\mathrm{C}(29)-\mathrm{C}(30)=177.1(8)^{\circ}$.

gen atoms of two DPPM ligands, a ${ }^{13} \mathrm{C}\left\{{ }^{1} \mathrm{H}\right\}$ NMR singlet for two symmetrically bridging carbonyls, a ${ }^{31} \mathrm{P}\left\{{ }^{1} \mathrm{H}\right\}$ NMR singlet for the four phosphorus atoms, and one bridging-carbonyl stretching band at $1670 \mathrm{~s} \mathrm{~cm}^{-1}$ observed in MeCN. The Ru-Ru distance of 2.7703(7) $\AA$ is significantly shorter than that of $2.841(1) \AA$ in $[1]^{+} 7$ or that of $2.830(4) \AA$ in $\left[\mathrm{Ru}_{2}(\mathrm{CO})_{3}(\mathrm{MeCN})(\mu \text {-DPPM })_{2}(u\right.$ $\mathrm{OAc})]^{+}{ }^{2}$ Apparently the presence of more electron donors (i.e., $\mathrm{MeCN}$ ) and fewer electron acceptors (i.e., $\mathrm{CO}$ ) causes the two ruthenium(I) atoms to form a stronger bond in [2] ${ }^{2+}$.

Upon addition of an excess of the uninegative anion $\mathrm{X}^{-}$to $[2]^{2+}$, we obtained, instead of the expected anionic substitution products such as $\left[\mathrm{Ru}_{2}(u-\mathrm{CO})_{2}(u-\mathrm{DPPM})_{2} \mathrm{X}_{4}\right]^{2-}$, the neutral diamagnetic adducts $\left[\mathrm{Ru}_{2}(\mu-\mathrm{CO})_{2}(\mu\right.$ DPPM $\left.)_{2} \mathrm{X}_{2}\right]\left(\mathrm{X}^{-}=\mathrm{Cl}^{-}(3 \mathbf{a}), \mathrm{Br}^{-}(\mathbf{3 b}), \mathrm{I}^{-}(\mathbf{3 c}), \mathrm{SH}^{-}(\mathbf{3 d})\right.$, Stol $^{-}$(3e), $\mathrm{S}^{i} \mathrm{Pr}^{-}(\mathbf{3 f}), \mathrm{N}_{3}^{-}(\mathbf{3 g})$ ) with a metal-metal triple bond, based on the 18-electron rule. ${ }^{8}$ The structure of $3 c$ (Figure 2) was determined by X-ray diffraction methods to adopt a geometry similar to that of $[2]^{2+} .9$ The Ru-Ru distance of 2.738 (2) $\AA$ in 3c, slightly shorter than that in $[\mathbf{2}]^{2+}$, is compatible with the presence of the $\mathrm{Ru}-\mathrm{Ru}$ multiple bond. The small difference (0.032(3) $\AA$ ) between the two values may be due to an electronic contribution from two terminal iodo groups. ${ }^{10}$ This is reflected by the relatively shorter $\mathrm{Ru}-\mathrm{I}$ distances

(6) Crystal data for [2][BF $]_{2}$ (instrument Siemens SMART-CCD): $\mathrm{C}_{60} \mathrm{H}_{56} \mathrm{~B}_{2} \mathrm{~F}_{8} \mathrm{~N}_{4} \mathrm{O}_{2} \mathrm{P}_{4} \mathrm{Ru}_{2}, \mathrm{FW}=1364.72$, crystal size $0.25 \times 0.20 \times 0.20$ $\mathrm{mm}$, monoclinic, P2 $1 / \mathrm{c}, \mathrm{a}=11.3231(2) \AA, \mathrm{b}=17.66110(10) \AA, \mathrm{c}=$ $16.0614(2) \AA, \beta=110.60(1)^{\circ}, V=3006.54(7) \AA^{3}, Z=2, D_{c}=1.508 \mathrm{~g}$ $\mathrm{cm}^{-3}, \mu(\mathrm{MoK} \alpha)=0.609 \mathrm{~mm}^{-1}, 6376$ unique reflections, temperature 293(2) $K, R=0.0556, R_{w}=0.1431$, goodness of fit indicator 1.110 . Hydrogen atoms were included but not refined.

(7) Sherlock, S. J .; Cowie, M.; Singleton, E.; Steyn, M. M. d. V. Organometallics 1988, 7, 1663 .

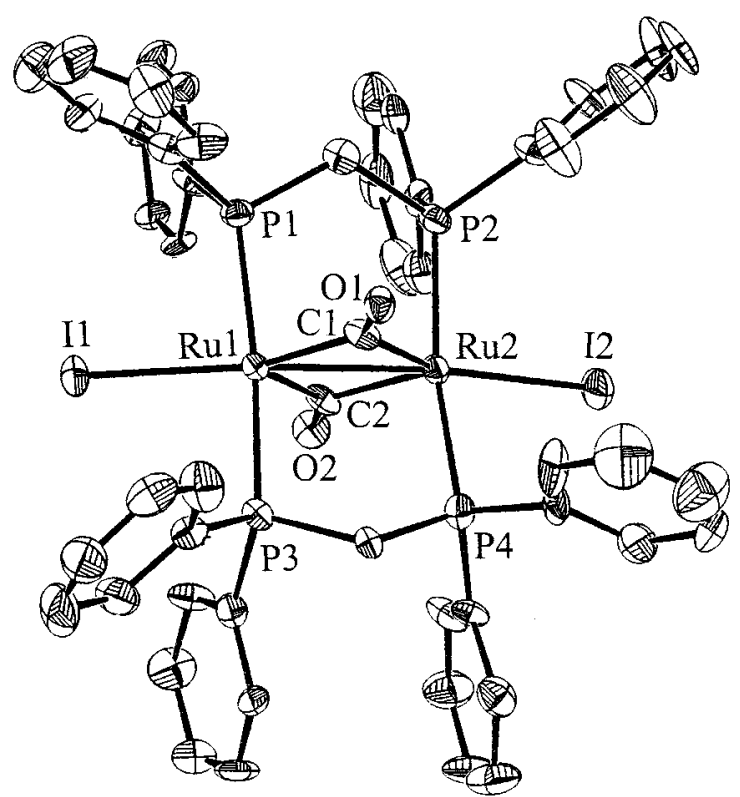

Figure 2. ORTEP diagram of $3 c$ showing $50 \%$ thermal ellipsoids with selected atom labels. Selected bond lengths $(\AA): R u(1)-R u(2)=2.738(2), R u(1)-I(1)=2.660(2)$, Ru$(1)-P(1)=2.349(6), R u(1)-P(3)=2.346(6), R u(1)-C(1)=$ 1.954(16), $\mathrm{Ru}(1)-\mathrm{C}(2)=1.95(2), \mathrm{C}(1)-\mathrm{O}(1)=1.18(2), \mathrm{C}(2)-$ $\mathrm{O}(2)=1.15(2), \mathrm{Ru}(2)-I(2)=2.679(2), \mathrm{Ru}(2)-\mathrm{P}(2)=2.357-$ (6), $\mathrm{Ru}(2)-\mathrm{P}(4)=2.349(6), \mathrm{Ru}(2)-\mathrm{C}(1)=1.99(2), \mathrm{Ru}(2)-$ $C(2)=2.013(16)$. Selected bond angles (deg): $R u(2)-$ $R u(1)-P(1)=93.90(15), R u(2)-R u(1)-P(3)=92.81(15)$, $R u(1)-R u(2)-P(2)=93.19(15), R u(1)-R u(2)-P(4)=93.83-$ (15), Ru(2)-Ru(1)-I(1) = 165.15(8), Ru(1)-Ru(2)-I(2) = 165.15(9), I(1)-Ru(1)-C(1) = 148.3(6), C(1)-Ru(1)-C(2) $=93.7(7), C(2)-R u(1)-I(1)=117.9(5), I(2)-R u(2)-C(1)=$ 149.4(5), $C(1)-R u(2)-C(2)=90.9(7), C(2)-R u(2)-I(2)=$ 119.7(6), Ru(1)-C(1)-Ru(2) = 88.0(7), Ru(1)-C(2)-Ru(2) $=87.3(7)$.

of 2.660(2) and 2.679(2) $\AA$ in 3c, in comparison with the typical terminal $\mathrm{Ru}(\mathrm{I})-\mathrm{I}$ distance of $2.767(2) \AA$ in $\left[R \mathrm{R}_{2^{-}}\right.$ $(u-\mathrm{I})(u$-CO $\left.)(\mathrm{CO})_{2}(u \text {-DPPM })_{2} \mathrm{I}\right] .^{12}$ However, the typical reactivity of the metal-metal multiple bond ${ }^{11 a, 13}$ is confirmed by the expected and unexpected adduct formation, as shown by the reactions of $\mathbf{3 a}$ and $\mathbf{3 b}$. With 2 equiv of $\mathrm{PhCH}_{2} \mathrm{NC}$, this complex was converted into $\left[\mathrm{Ru}_{2} \mathrm{Br}_{2}(u-\mathrm{CO})(\mathrm{CO})(u \text {-DPPM })_{2}\left(\mathrm{PhCH}_{2} \mathrm{NC}\right)_{2}\right](4) .{ }^{14} \mathrm{Un}$ fortunately, no single crystals of good quality have been grown as yet, and the structure of $\mathbf{4}$ is not known. The related spectral data indicate that the whole molecular

(8) The preparation procedures for $\mathbf{3 a}-\mathbf{g}$ are all similar, and a typical procedure for $\mathbf{3 c}$ is described below. In a $100 \mathrm{~mL}$ Schlenk flask was added [2]BF $4(0.100 \mathrm{~g}, 0.073 \mathrm{mmol}), \mathrm{Nal}(0.055 \mathrm{~g}, 0.367 \mathrm{mmol})$, and $10 \mathrm{~mL}$ of $\mathrm{MeCN}$ at ambient temperature. The mixture was then stirred for $1 \mathrm{~h}$. Filtration gave the orange-yellow product, which was then recrystallized from $\mathrm{CH}_{2} \mathrm{Cl}_{2} / \mathrm{MeCN}$ and dried in vacuo to give 0.062 $\mathrm{g}$ of the pure species $(67 \%)$.

(9) Crystal data for $3 \mathrm{c}$ (instrument Nonius CAD4): $\mathrm{C}_{52} \mathrm{H}_{44} \mathrm{I}_{2} \mathrm{O}_{2} \mathrm{P}_{4^{-}}$ $\mathrm{Ru}_{2} \cdot 2 \mathrm{CH}_{2} \mathrm{Cl}_{2}, \mathrm{FW}=1450.62$, crystal size $0.30 \times 0.40 \times 0.40 \mathrm{~mm}$ orthorhombic, Pna2 $1, a=29.302(5) \AA, b=15.541(2) \AA, c=12.329(2)$ $\AA, V=5614.7(15) \AA^{3}, Z=4, D_{c}=1.716 \mathrm{~g} \mathrm{~cm}^{-3}, \mu($ MoK $\alpha)=1.96 \mathrm{~mm}^{-1}$ 6723 unique reflections, temperature 298(2) $K, R=0.049, R_{w}=0.040$, goodness of fit indicator 1.37. Hydrogen atoms were included but not refined.

(10) Similar inductive lengthening on the metal-metal multiple bond was reported previously in the $\left\{\mathrm{MO}_{2}\right\}^{4+}$ and $\left\{\mathrm{Cr}_{2}\right\}^{4+}$ systems. ${ }^{11 b}$

(11) (a) Cotton, F. A., Walton, R. A., Eds. Multiple Bonds between Metal Atoms, 2nd ed.; Oxford University Press: New York, 1993. (b) Ibid., pp 157, 285

(12) Shiu, K.-B.; Guo, W.-N.; Chan, T.-J .; Wang, J .-C.; Liou, L.-S.; Peng, S.-M.; Cheng, M.-C. Organometallics 1995, 14, 1732.

(13) Chisholm, M. H., Ed. Reactivity of Metal-Metal Bonds; American Chemical Society: Washington, DC, 1981. 


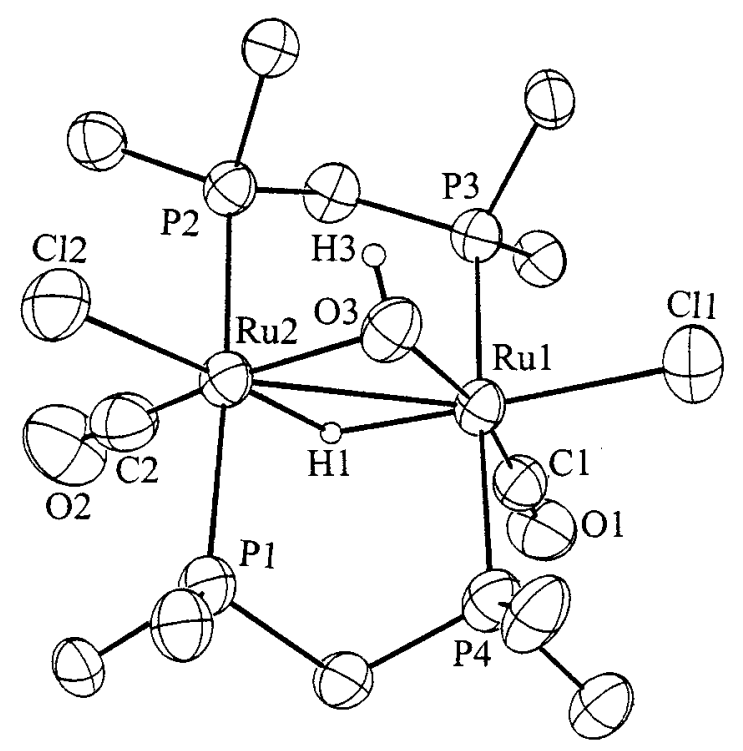

Figure 3. ORTEP diagram of $\mathbf{5 b}$ showing $50 \%$ thermal ellipsoids and numbering scheme (only the ipso carbon atoms of each phenyl group has been retained for clarity). Selected bond lengths $(\AA)$ : $R u(1)-\operatorname{Ru}(2)=2.8620(7)$, Ru$(1)-\mathrm{C}(1)=1.821(8), \mathrm{Ru}(2)-\mathrm{C}(2)=1.816(10), \mathrm{C}(1)-\mathrm{O}(1)=$ 1.152(9), $\mathrm{C}(2)-\mathrm{O}(2)=1.168(11), \mathrm{Ru}(1)-\mathrm{Cl}(1)=2.438(2)$, $\mathrm{Ru}(2)-\mathrm{Cl}(2)=2.4169(17), \mathrm{Ru}(1)-\mathrm{O}(3)=2.161(4), \mathrm{Ru}(2)-$ $\mathrm{O}(3)=2.182(5), \mathrm{Ru}(1)-\mathrm{P}(1)=2.3829(18), \mathrm{Ru}(2)-\mathrm{P}(1)=$ 2.3751(19), $\mathrm{Ru}(2)-\mathrm{P}(2)=2.3646(19), \mathrm{Ru}(1)-\mathrm{P}(3)=2.3829$ (18), $\mathrm{Ru}(1)-\mathrm{P}(4)=2.3719(19), \mathrm{Ru}(1)-\mathrm{H}(1)=1.797(10)$, Ru$(2)-H(1)=1.748(10), O(3)-H(3)=0.804(10)$. Sel ected bond angles (deg): $R u(1)-R u(2)-P(1)=91.90(5), R u(1)-R u(2)-$ $P(2)=91.73(5), R u(2)-R u(1)-P(3)=91.28(4), R u(2)-R u-$ $(1)-P(4)=91.68(5), P(1)-R u(2)-P(2)=175.97(7), P(3)-$ $\mathrm{Ru}(1)-\mathrm{P}(4)=176.02(6), \mathrm{Cl}(1)-\mathrm{Ru}(1)-\mathrm{O}(3)=97.60(14)$, $\mathrm{O}(3)-\mathrm{Ru}(1)-\mathrm{Ru}(2)=49.09(13), \mathrm{C}(1)-\mathrm{Ru}(1)-\mathrm{Cl}(1)=93.1-$ (2), $\mathrm{Ru}(1)-\mathrm{C}(1)-\mathrm{O}(1)=178.4(7), \mathrm{Ru}(1)-\mathrm{O}(3)-\mathrm{Ru}(2)=$ 82.44(17), $\mathrm{Cl}(2)-\mathrm{Ru}(2)-\mathrm{O}(3)=97.79(13), \mathrm{O}(3)-\mathrm{Ru}(2)-\mathrm{Ru}-$ $(1)=48.47(11), \mathrm{C}(2)-\mathrm{Ru}(2)-\mathrm{Cl}(2)=94.0(3), \mathrm{Ru}(2)-\mathrm{C}(2)-$ $\mathrm{O}(2)=177.7(8), \mathrm{Ru}(1)-\mathrm{H}(1)-\mathrm{Ru}(2)=35.6(1)$.

structure is asymmetric with one bridging carbonyl. With $\mathrm{Me}_{3} \mathrm{NO} \cdot 2 \mathrm{H}_{2} \mathrm{O}$, 3a was converted into two isomeric diamagnetic products, $\mathbf{5 a}$ and $\mathbf{5 b}$, with the formula $\left[\mathrm{Ru}_{2^{-}}\right.$ $\left.\mathrm{Cl}_{2}(\mathrm{CO})_{2}(\mu-\mathrm{DPPM})_{2}(\mu-\mathrm{H})(\mu-\mathrm{OH})\right]$, which can be separated by TLC. ${ }^{15}$ The ratio $\mathbf{5 a} / \mathbf{5 b}$ is 2.25 , based on the ${ }^{1} \mathrm{H}$ NMR evidence. Although the relevant formation mechanism is not known, good single crystals of the minor product $\mathbf{5 b}$ were grown successfully, and the solid-state structure was determined. I mportantly, this structure helps us to confirm the presence of two

(14) Procedure for 4: In a $100 \mathrm{~mL}$ Schlenk flask was added $\mathbf{3 b}$ (102 $\mathrm{mg}, 0.0865 \mathrm{mmol}$ ) and $10 \mathrm{~mL}$ of $\mathrm{CH}_{2} \mathrm{Cl}_{2}$. This solution was then added at $0{ }^{\circ} \mathrm{C}$ dropwise to $3.2 \mathrm{~mL}$ of benzyl isocyanide solution, preparing by dissolving $0.071 \mathrm{~g}(0.607 \mathrm{mmol})$ of it in $10 \mathrm{~mL}$ of $\mathrm{CH}_{2} \mathrm{Cl}_{2}$. After $10 \mathrm{~min}$, the solvent was stripped off under vacuum. Recrystallization from $\mathrm{CH}_{2-}$ $\mathrm{Cl}_{2} / \mathrm{MeOH}$ gave the pale yellow product 4 . Yield: $44 \mathrm{mg}(33 \%)$. terminal carbonyls, a bridging hydride, and a bridging hydroxide rather than a bridging oxide or aqua based on solution ${ }^{1} \mathrm{H}$ NMR and IR data. Clearly, the bridging hydride shows a virtual ${ }^{1} \mathrm{H}$ NMR quintet at $\delta-26.36$ for $\mathbf{5 a}$ and $\delta-25.04$ for $\mathbf{5 b}$, and the bridging hydroxide displays only one weak IR O-H stretching band at 3627 $\mathrm{cm}^{-1}$ for $\mathbf{5 a}$ and $3615 \mathrm{~cm}^{-1}$ for $\mathbf{5 b}$. I ndeed, the observed diamagnetic property indicates obviously that both Ru atoms are in the same formal oxidation state, $\mathrm{Ru}^{\prime \prime}$. The two terminal carbonyls are trans to the bridging hydroxide in $\mathbf{5 b}$ (Figure 3). ${ }^{16}$ The $\mathrm{Ru}^{11}-\mathrm{Ru} \mathrm{ll}^{\mathrm{ll}}$ distance of $2.8620(7) \AA$ in this compound indicates the presence of a single bond. Apparently the structure of the other isomer 5a contains a different orientation with the stronger $\sigma$-donor, the $\mu$-hydrido bridging ligand, trans to the carbonyls. This would explain why 5 a was formed in a larger quantity than $\mathbf{5 b}$.

In summary, we have described a novel transformation, starting from $[\mathbf{1}]^{+}$, passing through $[\mathbf{2}]^{2+}$, and ending in the series of dinuclear triply bonded compounds $3 \mathbf{a}-\mathbf{g}$. Also unusually, despite the presence of four bridging ligands surrounding the triple bond in these compounds, facile reactions of the bond are still accessible via relocation of one or two bridging carbonyls as shown to produce $\mathbf{4}$ and $\mathbf{5 a} \mathbf{a}, \mathbf{b}$ (Scheme 1). Further studies are in progress to obtain the solid-state structure for $\mathbf{4}$, to elucidate the formation mechanism of $\mathbf{5}$, and to extend the scope of reactions of $\mathbf{2}$ and $\mathbf{3}$ with various kinds of reagents.

Acknowledgment. We thank the National Science Council of the Republic of China for financial support of this research (Contract No. NSC88-2113-M 006-013).

Supporting Information Available: Text giving experimental procedures for the preparation and characterization of compounds and detailed lists of crystal data, atomic coordinates, anisotropic displacement parameters, and bond distances and angles for compounds $\mathbf{2}, \mathbf{3} \mathbf{c}$, and $\mathbf{5 b}$. This material is available free of charge via the Internet at http://pubs.acs.org.

\section{OM990513।}

(15) Procedure for $\mathbf{5 a}$ and $\mathbf{5 b}$ : A solution of $\mathbf{3 a}(0.158 \mathrm{~g}, 0.144 \mathrm{mmol})$ in $10 \mathrm{~mL}$ of $\mathrm{CH}_{2} \mathrm{Cl}_{2}$ was added dropwise to $2.1 \mathrm{~mL}$ of the $\mathrm{Me}_{3} \mathrm{NO}$ solution, prepared from $\mathrm{Me}_{3} \mathrm{NO} \cdot 2 \mathrm{H}_{2} \mathrm{O}(0.100 \mathrm{~g}, 0.901 \mathrm{mmol})$ dissolved in $10 \mathrm{~mL}$ of $\mathrm{MeOH}$. The solution was stirred for $36 \mathrm{~h}$, and the volatiles were pumped off. Two isomeric products were separated as major and minor yellow bands, respectively, by thin-layer chromatography (silica gel, $\mathrm{CH}_{2} \mathrm{Cl}_{2} /$ hexane 6:1) in a glovebox, using TLC plates (Kieselguhr $60 \mathrm{~F}_{254}, \mathrm{E}$. Merck), and recrystallized from $\mathrm{CH}_{2} \mathrm{Cl}_{2} /$ hexane, producing $25 \mathrm{mg}(16 \%$ yield) of $\mathbf{5 a}$ and $8 \mathrm{mg}(5 \%)$ of $\mathbf{5 b}$.

(16) Crystal data for $\mathbf{5 b}$ (instrument Siemens SMART-CCD): $\mathrm{C}_{52} \mathrm{H}_{46}$ $\mathrm{Cl}_{2} \mathrm{O}_{3} \mathrm{P}_{4} \mathrm{Ru}_{2} \cdot 2 \mathrm{H}_{2} \mathrm{O}, \mathrm{FW}=1151.84$, crystal size $0.33 \times 0.18 \times 0.13 \mathrm{~mm}$, orthorhombic, Pna2 $1, a=24.0411(9) \AA, b=12.4778(5) \AA, c=17.6573-$ (7) $\AA, V=5296.8(4) \AA^{3}, Z=4, D_{c}=1.444 \mathrm{~g} \mathrm{~cm}^{-3}, \mu($ Mo K $\alpha)=0.836$ $\mathrm{mm}^{-1}, 9801$ unique reflections, temperature 293(2) $\mathrm{K}, \mathrm{R}=0.0442, \mathrm{R}_{\mathrm{w}}$ $=0.1155$, goodness of fit indicator 1.006. Hydrogen atoms were included but not refined. 